\title{
Serotonin stimulates platelet receptor shedding by tumor necrosis factor-alpha-converting enzyme (ADAM17)
}

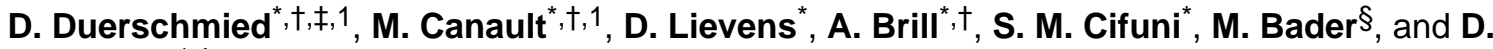 \\ D. Wagner ${ }^{*} \dagger$ \\ "Immune Disease Institute, Harvard Medical School, Boston, MA, USA \\ †Department of Pathology, Harvard Medical School, Boston, MA, USA \\ ‡Cardiology and Angiology, University Hospital of Freiburg, Freiburg \\ $\S$ Max Delbrück Centre for Molecular Medicine, Berlin, Germany
}

\section{Summary}

Background-Peripheral serotonin (5-hydroxytryptamine, 5-HT) is transported by platelets and released upon stimulation. In the platelet cytoplasm, 5-HT is transamidated to small GTPases, promoting $\alpha$-granule release and primary hemostasis.

Objective-We hypothesized that 5-HT could also stimulate platelet receptor shedding after binding to the membrane 5-HT receptor (5-HT2AR).

Methods-Western blot and flow cytometry were used to determine levels of the adhesion receptor glycoprotein (GP)Ib $\alpha$ on platelets or its shed fragment glycocalicin in plasma and serum from wild-type mice, $\mathrm{Tph} 1^{-1-}$ mice lacking peripheral 5-HT, and mice lacking functional tumor necrosis factor-alpha-converting enzyme (TACE, ADAM17). Flow chamber experiments and intravital microscopy were used to examine the adhesive properties of platelets after stimulation of 5-HT2AR.

Results-Glycocalicin was significantly reduced in $\mathrm{Tph} 1^{-/-}$plasma and serum. In isolated platelets, 5-HT induced shedding of GPIb $\alpha$, which was increased to $60 \%$ when 5-HT uptake was inhibited by the selective serotonin reuptake inhibitor fluoxetine. Specific 5-HT2AR agonism and antagonism suggested activation of this receptor. The shedding could not be induced in

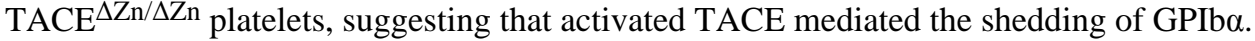
Intracellular signaling involved phosphorylation of p38 mitogen-activated protein kinase rather than G-protein signaling. 5-HT2AR stimulation decreased platelet adhesion to collagen-bound von Willebrand factor under arterial shear $\left(1500 \mathrm{~s}^{-1}\right)$ and incorporation into $\mathrm{FeCl}_{3}$-induced thrombi in mesenteric arterioles.

(C) 2009 International Society on Thrombosis and Haemostasis

Correspondence: Denisa D. Wagner, Immune Disease Institute, 3 Blackfan Circle, 3rd Floor, Boston, MA 02115, USA. Tel.: +1 617

713 8300; fax: +1 617713 8333. wagner@idi.harvard.edu.

1 These authors contributed equally to this study.

Disclosure of Conflict of Interests

The authors state that they have no conflict of interest.

Supporting Information

Additional Supporting Information may be found in the online version of this article:

Fig. S1. Stimulation of 5-HT2AR induces activation of TACE, but not ADAM10.

Please note: Wiley-Blackwell are not responsible for the content or functionality of any supporting materials supplied by the authors.

Any queries (other than missing material) should be directed to the corresponding author for the article. 
Conclusions-Stimulation of 5-HT2AR on platelets induces TACE-mediated shedding of GPIb $\alpha$, the key adhesion molecule under high shear conditions. Our observations demonstrate a new pathway through which 5-HT could modulate cardiovascular disease.

\section{Keywords}

5-HT2AR; GPIb $\alpha$; platelet; serotonin; TACE

\section{Introduction}

Serotonin (5-hydroxytryptamine, 5-HT) is not only an important neurotransmitter but is also a peripheral hormone that is transported by platelets. In platelets, 5-HT is stored in dense granules at millimolar concentrations [1]. To promote hemostasis, activated platelets release 5-HT, which induces vasoconstriction and amplifies platelet activation at the site of vessel wall injury $[2,3]$. The latter is mediated mainly by transamidation of 5-HT to small GTPases ('serotonylation') and consecutive $\alpha$-granule release [4]. Two serotonergic components are present on the platelet surface, the 5-HT transporter (SERT) and the 5-HT2A receptor (5HT2AR) [5,6]. Activation of 5-HT2AR stimulates the uptake of 5-HT into the platelet via SERT, and both $\mathrm{Ca}^{2+}$ mobilization after 5-HT2AR activation and increase of intracellular 5HT concentration promote serotonylation [4].

Other functions of peripheral 5-HT include mitogenic effects on hepatocytes [7] and pulmonary artery smooth muscle cells [8], regulation of embryonic development [9] and intestinal motility [10]. Peripheral 5-HT also stimulates lymphocytes [11] and monocytes [12]. It was recently reported that stimulation of 5-HT2AR in renal mesangial cells activates tumor necrosis factor-alpha-converting enzyme (TACE; a disintegrin and metalloproteinase-17, ADAM17), resulting in shedding of heparin-bound epidermal growth factor (HB-EGF), activation of EGF receptor, and extracellular signal-regulated kinase phosphorylation [13]. As 5-HT2AR and TACE are also present on platelets, we hypothesized that 5-HT2AR stimulation could also activate TACE on platelets.

Our group previously demonstrated that TACE is the key enzyme mediating shedding of the adhesion molecule glycoprotein (GP)Ib $\alpha$ from platelets to regulate its surface expression [14]. GPIb $\alpha$ is essential for the recruitment of platelets to both subendothelium and thrombi under arterial flow conditions [15-17]. Here, we show that stimulation of 5-HT2AR on murine platelets induced shedding of GPIb $\alpha$ by TACE, which decreased adhesive properties of the platelets. Because 5-HT is also efficiently transported into the platelet cytoplasm by SERT and is then no longer available for 5-HT2AR stimulation, blocking of SERT by a selective serotonin reuptake inhibitor (SSRI) further increased TACE activation.

\section{Materials and methods}

\section{Reagents and antibodies}

Prostacyclin [prostaglandin $\mathrm{I}_{2}\left(\mathrm{PGI}_{2}\right)$ ], fluoxetine, 5-HT hydrochloride, (-)-2,5dimethoxy-4-iodoamphetamine hydrochloride (DOI), ketanserin, thrombin, phorbol 12myristate 13-acetate (PMA) and U73122 were purchased from Sigma-Aldrich (St Louis, MO, USA), enoxaparin from Sanofi-Aventis (Bridgewater, NJ, USA), SB203580, SB202190, tumor necrosis factor-alpha protease inhibitor (TAPI-1), BAPTA, pertussis toxin, wortmannin and Ro31-8220 from Calbiochem (San Diego, CA, USA), and $\left[{ }^{14} \mathrm{C}\right]$ serotonin from Amersham Biosciences (Piscataway, NJ, USA). Monoclonal antibodies against GPIb $\alpha$, GPV, GPVI, CD9, integrin $\alpha_{5}$ and activated integrin $\alpha_{\mathrm{IIb}} \beta_{3}$ were purchased from Emfret Analytics (Wuerzburg, Germany) and monoclonal anti-P-selectin from BD Pharmingen (San Jose, CA, USA). Annexin V was from Molecular Probes (Eugene, OR, 
USA), monoclonal anti-mouse p38 mitogen-activated protein kinase (MAPK) was from Cell Signaling Technology (Danvers, MA, USA), and horseradish peroxidase-conjugated antirabbit IgG was from Southern Biotech (Birmingham, AL, USA).

Mice

C57BL/6J mice, 6-8 weeks old, were purchased from Jackson Laboratory (Bar Harbor, ME, USA). TACE ${ }^{+/ \Delta \mathrm{Zn}}$ mutant mice (C57BL/6J/129Sv background) [18] were kindly provided by J. Peschon (Amgen, Seattle, WA, USA). TACE ${ }^{\Delta \mathrm{Zn} / \Delta \mathrm{Zn}}$ and $\mathrm{TACE}^{+/+}$chimeric mice were

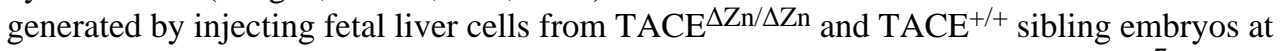
day 16.5 of development into irradiated C57BL/6J recipient mice $\left(12.5 \mathrm{~Gy} ; 1 \times 10^{7}\right.$ cells per mouse). Tph $1^{-/-}$mice [19] and interleukin-4 receptor $\alpha$ (IL-4R $\alpha$ )/GPIb $\alpha$ transgenic mice [20] (kindly provided by J. Ware, University of Arkansas for Medical Sciences, Little Rock, AR, USA) were also on a C57BL/6J background. All mice were bred and housed in our animal facility. Experimental procedures were approved by the Animal Care and Use Committee of the Immune Disease Institute.

\section{Blood collection, 5-HT uptake, and 5-HT levels}

Isofluorane-anesthetized mice were bled from the retro-orbital sinus into $100 \mu \mathrm{g} \mathrm{mL}{ }^{-1}$ enoxaparin. Platelet-rich plasma (PRP) was obtained by $2 \times 5$ min of centrifugation at $100 \times$ g. PRP was incubated with fluoxetine for $10 \mathrm{~min}$, and then with $\left[{ }^{14} \mathrm{C}\right] 5-\mathrm{HT}\left(57 \mathrm{mCi} \mathrm{mmol}{ }^{-1}\right.$ $\mathrm{mL}^{-1}$ ) for $30 \mathrm{~min}$ at $37^{\circ} \mathrm{C}$. 5-HT uptake was terminated by adding one volume of $4 \%$ icecold paraformaldehyde solution. The samples were then centrifuged at $2500 \times g$ for $5 \mathrm{~min}$, and the supernatants were used for scintillation counting. Total $\left[{ }^{14} \mathrm{C}\right] 5-\mathrm{HT}$ was determined in samples lysed with $0.5 \%$ Triton X-100. 5-HT levels were quantified by enzyme immunoassay according to the manufacturer's instructions (Labor Diagnostika Nord, Nordhorn, Germany).

\section{Flow cytometry and 5-HT2AR stimulation}

PRP was centrifuged at $700 \times g$ in the presence of $\mathrm{PGI}_{2}(2 \mu \mathrm{g} \mathrm{mL}-1)$ for $5 \mathrm{~min}$. Pelleted platelets were resuspended in modified Tyrode's buffer ( $137 \mathrm{~m}_{\mathrm{M} \mathrm{NaCl}}, 0.3 \mathrm{~m}_{\mathrm{M}} \mathrm{Na}_{2} \mathrm{HPO}_{4}, 2$ $\mathrm{m}_{\mathrm{M}} \mathrm{KCl}, 12$ mм $\mathrm{NaHCO}_{3}, 5$ mм HEPES, 11 mм glucose, $\mathrm{pH} 7.3$ ) containing $0.18 \%$ bovine serum albumin. The platelet concentration was adjusted to $2 \times 10^{8} \mathrm{~mL}^{-1}$. After $10 \mathrm{~min}$ of incubation with fluoxetine, 5 -HT or DOI was added $\left(37^{\circ} \mathrm{C}\right)$. Where indicated, platelets were incubated with thrombin for $10 \mathrm{~min}$. All control samples were treated with equal concentrations of the vehicle, dimethylsulfoxide (DMSO). Signaling molecules were inhibited by coincubation with inhibitors from lots that were confirmed to be functionblocking in flow cytometry and/or aggregometry. Platelets were then incubated with an excess of antibody for $5 \mathrm{~min}$ and immediately read on a FACScalibur (BD Biosciences, San Jose, CA, USA). For detection of exposed phosphatidylserine, samples were incubated with annexin $\mathrm{V}$ for $5 \mathrm{~min}$ in the presence of $2.5 \mathrm{mM} \mathrm{CaCl}_{2}$. Data were analyzed with $\mathrm{F}_{\text {Low }} \mathrm{J}_{\mathrm{o}}$ software (Tree Star, Ashland, OR, USA) after gating on the platelet population according to forward/sideward scatter characteristics.

\section{Immunoblot and p38 MAPK phosphorylation}

Plasma was obtained from PRP containing $\mathrm{PGI}_{2}(2 \mu \mathrm{g} \mathrm{mL}-1)$ by pelleting platelets at $700 \times$ $g$ for $5 \mathrm{~min}$, and then centrifuging the supernatant at $16000 \times g$ for $5 \mathrm{~min}$. Total protein was determined with the BCA Protein Assay Kit (Pierce, Rockford, IL, USA). Samples were diluted with Laemmli sample buffer (Bio-Rad, Hercules, CA, USA) containing $\beta$ mercaptoethanol, and $40 \mu \mathrm{g}$ of protein was separated by sodium dodecylsulfate polyacrylamide gel electrophoresis and transferred onto a poly(vinylidene difluoride) membrane. Glycocalicin was detected with anti-GPIb $\alpha$ clone Xia.G7 (Emfret) and total 
protein with Coomassie blue. For platelet lysates, treated platelets were pelleted and lysed with RIPA buffer (Cell Signaling) containing protease inhibitor cocktail Complete EDTAfree (Roche Diagnostics, Indianapolis, IN, USA). Phosphorylated p38 MAPK in lysates of 5 $\times 10^{5}$ platelets was determined with the PathScan Phospho-p38 MAPK Sandwich enzymelinked immunosorbent assay (ELISA) Kit (Cell Signaling, with reported 0.4 arbitrary units in untreated fibroblasts vs. 2.8 in UV-treated fibroblasts) and read at $450 \mathrm{~nm}$. Total p38 MAPK was determined by western blot with anti-p38 MAPK antibody (Cell Signaling).

\section{Flow chamber and aggregometry}

Platelets were isolated from blood containing $40 \mu_{\mathrm{M}}$ PPACK and $20 \mu \mathrm{g} \mathrm{mL}^{-1}$ enoxaparin, treated with the vehicle (DMSO) or $20 \mu_{\mathrm{M}}$ fluoxetine plus $50 \mu_{\mathrm{M}}$ DOI for $60 \mathrm{~min}$, and labeled with $2.5 \mathrm{mg} \mathrm{mL}^{-1}$ calcein orange (Molecular Probes). Platelet-poor blood was reconstituted with remaining plasma and $2 \times 10^{8} \mathrm{~mL}^{-1}$ platelets. Using a $0.0127-\mathrm{cm}$ silicon rubber gasket, a parallel plate flow chamber (Glycotech, Gaithersburg, MD, USA) was assembled onto 35$\mathrm{mm}$-diameter round glass coverslips, which had been coated with $100 \mu \mathrm{g} \mathrm{mL}^{-1}$ collagen (Nycomed, Munich, Germany) and perfused at $1500 \mathrm{~s}^{-1}$ for $2 \mathrm{~min}$. Platelet adhesion was monitored with an Axiovert 135 inverted microscope (Zeiss, Jena, Germany) at $\times 32$ magnification using a C2400 camera (Hamamatsu Photonics, Hamamatsu City, Japan) and analyzed with IMAGE SXM 1.62 (NIH Image). Aggregation of isolated, vehicle (DMSO)treated or fluoxetine $\left(20 \mu_{\mathrm{M}}\right) / 5-\mathrm{HT}(50 \mu \mathrm{M})$-treated platelets (60 min of incubation) was assayed with $10 \mu_{\mathrm{M}} \mathrm{ADP}$ as previously described [21].

\section{Mesentery arteriole thrombosis}

Male mice, 4-5 weeks old, were anesthetized with intraperitoneal 2.5\% tribromoethanol (15 $\mu \mathrm{L} \mathrm{g}^{-1}$ body weight; Avertin). Isolated platelets were treated with DMSO or fluoxetine (20 $\left.\mu_{\mathrm{M}}\right)$ plus 5 -HT $\left(100 \mu_{\mathrm{M}}\right)$ for $60 \mathrm{~min}$, and calcein-labeled as described above. To obtain 1\% labeled platelets, either $2.5 \times 10^{9} \mathrm{~kg}^{-1}$ vehicle-treated platelets or $7.5 \times 10^{9} \mathrm{~kg}^{-1}$ fluoxetine/ 5-HT-treated platelets were injected into the retro-orbital sinus of each mouse. A loop of intestine was exteriorized, and an arteriole with a diameter of $\sim 100 \mu \mathrm{m}$ and a measured shear rate of 1000-2500 s ${ }^{-1}$ (determined with an Optical Doppler Velocimeter, Microcirculation Research Institute, Texas A\&M University, College Station, TX, USA) was visualized. Thrombus formation was induced by topical application of a $10 \% \mathrm{FeCl}_{3^{-}}$ soaked filter paper, and evaluated with an Axiovert 200M inverted microscope, and an AxioCam MRm camera, using AxIovision REL. 4.6 software (Zeiss).

\section{Statistical analysis}

Data are presented as mean \pm standard error of the mean and were analyzed by unpaired, two-tailed Student's $t$-test or anova with Bonferroni's correction. $P$-values $<0.05$ were regarded as statistically significant.

\section{Results}

\section{Glycocalicin is reduced in plasma and serum from mice that lack peripheral 5 -HT}

The metalloproteinase TACE downregulates surface GPIb $\alpha$ by causing it to shed its 130$\mathrm{kDa}$ extracellular domain as glycocalicin [14]. The absence of TACE activity in $\mathrm{TACE}^{\Delta \mathrm{Zn} / \Delta \mathrm{Zn}}$ chimeric mice results in a $90 \%$ reduction of glycocalicin in plasma [14]. To test the hypothesis that 5-HT is involved in the shedding of GPIb $\alpha$, we assessed glycocalicin levels in plasma and serum of mice that do not express tryptophan hydroxylase 1 (TPH1). TPH1 is the rate-limiting enzyme for the synthesis of peripheral 5-HT [19]. As peripheral 5HT is not produced, platelets cannot take it up to store and release it upon activation. We 
measured a mean 5-HT level in Tph1 ${ }^{-/-}$serum of $0.05 \mu \mathrm{g} \mathrm{mL}^{-1}\left(\sim 0.2 \mu_{\mathrm{M}}\right) \mathrm{vs.} 2 \mu \mathrm{g} \mathrm{mL} L^{-1}(\sim$ $\left.10 \mu_{\mathrm{M}}\right)$ in wild-type serum $(P<0.001, n=4)$.

Using western blot analysis, we found that platelet-free plasma from $\mathrm{Tph} 1^{-/-}$mice contained significantly less glycocalicin than wild-type plasma (Fig. 1A), suggesting that less GPIb $\alpha$ is shed in the normal circulation if 5-HT is absent. The glycocalicin level was also significantly reduced in Tph $1^{-/-}$serum (Fig. 1B). The negative control plasma and serum from IL-4R $\alpha /$ GPIb $\alpha$-tg mice lacking the extracellular domain of GPIb $\alpha$ did not contain detectable amounts of glycocalicin.

The reduction of glycocalicin in 5-HT-deficient serum could be a combined effect of smaller amounts being present in plasma and altered platelet activation by thrombin. During serum formation, in vitro coagulation occurs and generates thrombin, leading to platelet activation [22]. Activated platelets secrete $\alpha$-granule and dense granule contents, including 5-HT, which in turn stimulates platelet 5-HT2AR. Thrombin is known to also activate TACE and induce GPIb $\alpha$ shedding itself [14]. Therefore, we examined GPIb $\alpha$ surface expression by flow cytometry after treatment of isolated platelets from wild-type and $\mathrm{Tph} 1^{-/-}$mice with thrombin (Fig. 1C). Equal concentrations of thrombin induced a significantly smaller decrease of surface GPIb $\alpha$ in platelets from Tph1 $1^{-/-}$mice, suggesting that 5-HT is involved in the activation of TACE by thrombin.

\section{Stimulation of the platelet 5-HT2A receptor induces shedding of GPIba mediated by TACE}

The observed phenotype of Tph $1^{-/-}$mice could be due to a defect in platelet activation (because serotonylation is absent) or to a lack of receptor-mediated serotonergic action. To address this issue, we compared stimulation of freshly isolated wild-type platelets with 5-HT to stimulation with another agonist of 5-HT2AR (Fig. 2A). Surface GPIb $\alpha$ levels decreased significantly in the presence of $100 \mu_{\mathrm{M}}$ 5-HT. This effect was amplified when 5-HT uptake was inhibited by the SSRI fluoxetine (Fig. 2A; a representative histogram is shown in Fig. S1A). We used a fluoxetine concentration of $20 \mu_{\mathrm{M}}$ for these experiments, because the uptake of ${ }^{14} \mathrm{C}$-labeled 5-HT into isolated platelets was inhibited by fluoxetine with an $\mathrm{IC}_{50}$ of $\sim 5 \mu_{\mathrm{M}}$ and an $\mathrm{IC}_{90}$ of $\sim 20 \mu_{\mathrm{M}}$ (not shown). Fluoxetine alone also significantly decreased the level of surface GPIb $\alpha$, which could be due to an interruption of the continuous 5-HT recycling in platelets [23] with increased 5-HT2AR stimulation. The 5-HT2AR antagonist ketanserin $\left(20 \mu_{\mathrm{M}}\right)$ reversed the effect of fluoxetine plus 5-HT (not significantly different from ketanserin alone), and the selective 5-HT2AR agonist DOI [24] (50 $\left.\mu_{\mathrm{M}}\right)$ elicited a similar response as 5-HT, further indicating that the decrease in the amount of surface GPIb $\alpha$ was induced by activation of 5-HT2AR.

Serotonin decreased the amount of surface GPIb $\alpha$ in a dose-dependent manner in the presence of fluoxetine, the decrease reaching a maximum of $\sim 60 \%$ with $100 \mu_{\mathrm{M}} 5-\mathrm{HT}$ (Fig. 2B). When incubating platelets with fluoxetine and $100 \mu_{\mathrm{M}} 5$-HT, we found that the decrease in GPIb $\alpha$ amount was time-dependent, with a maximum after $60 \mathrm{~min}$ (Fig. 2C). The amount of surface GPV, another TACE substrate [25], decreased accordingly upon treatment with $100 \mu_{\mathrm{M}} 5$-HT, and this decrease was significantly enhanced by $20 \mu_{\mathrm{M}}$ fluoxetine (Fig. S1B).

To confirm that the loss of surface GPIb $\alpha$ was mediated by active TACE, we coincubated wild-type and TACE ${ }^{\Delta \mathrm{Zn} / \Delta \mathrm{Zn}}$ platelets with the TACE inhibitor TAPI-1 $\left(5 \mu_{\mathrm{M}}\right)$ and treated them with $20 \mu_{\mathrm{M}}$ fluoxetine and $50 \mu_{\mathrm{M}}$ DOI. In either case, GPIb $\alpha$ levels did not change significantly (Fig. 2D), supporting our previous findings that stimulation of $\mathrm{TACE}^{\Delta \mathrm{Zn} / \Delta \mathrm{Zn}}$ platelets with agonists such as PMA or thrombin does not lead to glycocalicin release [14]. To confirm that GPIb $\alpha$ was shed, we determined the glycocalicin level in the supernatant of isolated, 5-HT2AR-stimulated platelets by western blot (Fig. 2E). We found a dosedependent appearance of glycocalicin in the supernatant, accompanied by a loss of GPIb $\alpha$ in 
platelet lysates of the same samples. The shedding did not reach the levels seen in samples

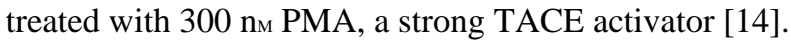

Fluoxetine at $20 \mu_{\mathrm{M}}$ and $5-\mathrm{HT}$ at $100 \mu_{\mathrm{M}}$ or DOI at $50 \mu_{\mathrm{M}}$, concentrations that induced strong GPIb $\alpha$ shedding, did not lead to general platelet activation. We found resting platelet levels of expression of the $\alpha$-granule protein P-selectin and of activated integrin $\alpha_{\mathrm{IIb}} \beta_{3}$ (not shown). Other surface proteins, such as integrin $\alpha_{5}$ and CD9, were not downregulated and phosphatidylserine was not upregulated (not shown). GPVI, the substrate of ADAM10 [26], was not shed (Fig. S1B). Moreover, neither 5-HT2AR-stimulated ( $20 \mu_{\mathrm{m}}$ fluoxetine plus 50 $\mu_{\mathrm{M}}$ DOI) nor vehicle-treated platelets aggregated unless stimulated with ADP (not shown). Therefore, 5-HT2AR-stimulated platelets shed GPIb $\alpha$ and GPV, but displayed other characteristics of resting platelets.

\section{GPIba shedding after 5-HT2AR stimulation relies on p38 MAPK rather than G-protein signaling}

The key mechanism by which 5-HT supports primary hemostasis is $\alpha$-granule release after an increase in intracellular 5-HT and subsequent serotonylation of small GTPases [4]. As 5HT2AR stimulation promotes serotonylation, we wanted to know whether serotonylation might also be involved in the activation of TACE. The shedding of GPIb $\alpha$ after 5-HT2AR stimulation (20 $\mu_{\mathrm{M}}$ fluoxetine plus $\left.50 \mu_{\mathrm{M}} \mathrm{DOI}\right)$ in platelets from Tph1 ${ }^{-/-}$mice, which lack intracellular 5-HT and hence the capacity for serotonylation, was comparable to that of the wild type and was also inhibited by TAPI-1 (Fig. 3A and Fig. S1A). This suggests that intracellular serotonylation was not involved in TACE-mediated GPIb $\alpha$ shedding.

The intracellular signal transduction after stimulation of the G-protein-coupled 5-HT2AR in platelets combines serotonylation and second messenger signaling with $\mathrm{Ca}^{2+}[4,27]$. After receptor activation, $\mathrm{G} \alpha_{\mathrm{q}}$-mediated activation of phospholipase $\mathrm{C}$ (PLC) releases inositol 1,4,5-trisphosphate and diacylglycerol. This mobilizes intracellular $\mathrm{Ca}^{2+}$ and activates protein kinase $\mathrm{C}(\mathrm{PKC})$. To test the involvement of components of this pathway, we coincubated platelets with different inhibitors during 5-HT2AR stimulation. GPIb $\alpha$ shedding was not prevented by $10 \mu \mathrm{g} \mathrm{mL}-1$ pertussis toxin (Ptx), $10 \mu_{\mathrm{M}}$ PLC inhibitor (U73122), $5 \mu \mathrm{g}$ $\mathrm{mL}^{-1}$ PKC inhibitor (Ro31-8220), or $30 \mu_{\mathrm{M}}$ BAPTA (Fig. 3B,C). This suggests that Ptxsensitive G-proteins, PLC, PKC and intracellular $\mathrm{Ca}^{2+}$ (chelated with BAPTA) were not involved. Accordingly, the inhibition of phosphoinositide 3-kinase with wortmannin (5 $\left.\mu_{\mathrm{M}}\right)$ did not prevent GPIb $\alpha$ shedding (not shown).

In contrast, the inhibition of p38 MAPK by SB203580 (20 $\left.\mu_{\mathrm{M}}\right)$ completely abolished GPIb $\alpha$ shedding (Fig. 3D), suggesting that p38 MAPK regulates TACE activation after 5-HT2AR stimulation. We found very similar results when using another inhibitor of p38 MAPK, SB202190 (20 $\mu_{\mathrm{M}}$, not shown). To test whether 5-HT2AR stimulation by $100 \mu_{\mathrm{M}} 5$-HT in the presence of $20 \mu_{\mathrm{M}}$ fluoxetine induced phosphorylation of p38 MAPK, we determined the levels of phospho-p38 MAPK by ELISA after 0, 15, 30, and $60 \mathrm{~min}$. We found significantly increased phosphorylation of p38 MAPK (maximum after $15 \mathrm{~min}$ ) without an effect on the levels of p38 MAPK protein in the platelets (Fig. 3E). These results indicate that GPIb $\alpha$ shedding mediated by TACE after stimulation of 5-HT2AR requires activation of p38 MAPK, but not the traditional 5-HT signaling pathways, in platelets.

\section{Adhesive properties of platelets are decreased after stimulation of 5-HT2AR}

In flow chamber experiments, labeled 5-HT2AR-stimulated platelets ( $20 \mu_{\mathrm{M}}$ fluoxetine/50 $\mu_{\mathrm{M}}$ DOI) reconstituted in whole blood showed significantly impaired primary adhesion to collagen-bound von Willebrand factor (VWF) under arterial shear rates (Fig. 4A). This in 
vitro study suggests that the 5-HT-induced loss of GPIb $\alpha$ is sufficient to limit these platelets' adhesive function.

We next investigated whether 5-HT2AR stimulation also decreased the ability of the platelets to be incorporated into arterial thrombi in vivo. Isolated and treated platelets (fluoxetine/5-HT or vehicle) were washed (to avoid systemic injection of reagents) and then injected into young recipient mice. When equal amounts were injected into different mice, fewer 5-HT2AR-stimulated platelets were detected after $10 \mathrm{~min}$, possibly because they were preferentially cleared from the circulation. A three-fold higher amount of 5-HT2ARstimulated platelets had to be injected to yield $1 \%$ circulating platelets. The time to vessel occlusion (driven by endogenous platelets) after endothelial denudation by $10 \% \mathrm{FeCl}_{3}$ was similar between the groups $(P=0.760, n=5)$, but only a few 5-HT2ARstimulated platelets were incorporated into the growing thrombus (Fig. 4B). These findings suggest that TACEmediated GPIb $\alpha$ shedding after activation of 5-HT2AR decreases the ability of platelets to be incorporated into arterial thrombi.

\section{Discussion}

\section{5-HT deficiency affects platelet adhesion receptor shedding}

On the basis of our observation that glycocalicin levels in plasma and serum of Tph1 $1^{-/-}$ mice were reduced as compared with the wild type, we concluded that 5-HT is involved in the shedding of GPIb $\alpha$ from platelets. Glycocalicin is normally present in plasma of humans and mice [28], and platelet activation by different agonists, including thrombin, greatly increases its generation [14]. In isolated platelets that were activated with thrombin, we saw a defect in downregulation of surface GPIb $\alpha$ in platelets from $\mathrm{Tph} 1^{-1-}$ mice, and postulated that a lack of 5-HT2AR stimulation accounted for this defect. Whether glycocalicin levels might change in patients treated chronically with SSRI, who are depleted of platelet 5-HT but retain free plasma 5-HT [29], is an interesting question. The physiologic role of plasma glycocalicin itself remains unknown. Although plasma glycocalicin was diminished, resting GPIb $\alpha$ levels on platelets from Tph $1^{-/-}$mice were not higher than those on wild-type platelets. This is similar to what is seen in TACE ${ }^{\Delta \mathrm{Zn} / \Delta \mathrm{Zn}}$ mice, which have normal GPIb $\alpha$ levels on platelets but greatly reduced plasma glycocalicin levels [14].

\section{Stimulation of 5-HT2AR is a new mechanism of TACE activation}

Although GPIb $\alpha$ is a key adhesion receptor on platelets, knowledge about its shedding via TACE and the mechanisms that activate TACE remains incomplete. We show here that 5HT2AR agonists induce TACE-mediated shedding of GPIb $\alpha$ in isolated platelets, especially when 5-HT uptake into platelets by SERT is blocked. Effective 5-HT concentrations were determined systematically in the presence of fluoxetine in vitro, and were 1000-fold higher (micromolar) than normal plasma 5-HT concentrations (nanomolar). As platelet-dense granules contain $65 \mathrm{~m}_{\mathrm{M}}$ 5-HT [1], it is possible that effective 5-HT concentrations can be reached when platelets release 5-HT. Venous plasma 5-HT concentrations distal to an occluding coronary artery thrombus in dogs increased 500-fold in a study by Benedict et al. [30].

Other platelet responses were not activated by 5 -HT2AR stimulation, including integrin $\alpha_{\text {IIb }} \beta_{3}$ activation. This was expected, because 5-HT is known not to activate platelets by itself, but merely to enhance thrombin-induced or ADP-induced activation as a 'helper agonist' [2]. It was only by inhibiting the transport of intracellular 5-HT into dense granules in addition to preventing its secretion from platelet cytoplasm, and thereby artificially increasing intracellular 5-HT concentrations, that aggregation could be induced by 5-HT treatment [4]. 


\section{Intracellular signaling involves p38 MAPK, and bypasses classic pathways of 5-HT action}

The known signaling pathway after stimulation of the G-protein-coupled 5-HT2AR on platelets involves activation of PLC and PKC and mobilization of intracellular $\mathrm{Ca}^{2+}$, which supports serotonylation of small GTPases [4,6,27]. Surprisingly, inhibition of these pathways did not abolish GPIb $\alpha$ shedding in 5-HT/fluoxetine-treated platelets, but tended to enhance it. It is possible that this was due to a negative feedback loop. A negative feedback loop from PKC to 5-HT2AR has been described in neurons [31]. It was shown in other cell types that certain signaling molecules can bypass G-proteins by directly binding to Gprotein-coupled receptors [32]. In neutrophils, a p38 MAPK signalosome is recruited to an endocytosed G-protein-coupled receptor [33]. Our group has recently found that activation of TACE in platelets during storage and oxidative stress was mediated by p38 MAPK (Canault et al. and Brill et al., unpublished data). Our results show that TACE activation in 5-HT/fluoxetine-treated platelets is linked to phosphorylation of p38 MAPK, and it is possible that p38 MAPK interacts directly with 5-HT2AR in platelets.

Combining our new findings with known serotonergic actions in platelets, we propose the following model (Fig. 5). At low concentrations, 5-HT is transported into the platelet via SERT and into dense granules via the monoamine vesicular transporter 2 for storage and secretion upon activation [1,5]. Higher 5-HT concentrations can amplify the effects of other platelet activators and induce serotonylation of small GTPases, enhancing $\alpha$-granule release and promoting hemostasis [4]. Stimulation of 5-HT2AR alone activates p38 MAPK, which activates TACE to shed GPIb $\alpha$ and GPV from the VWF receptor complex GPIb-IX-V.

\section{Possible clinical relevance of our studies}

Isolated platelets that were treated with 5-HT2AR agonists while SERT was blocked showed defective adhesion under arterial shear both in vitro and in vivo. It is not known to what extent platelet 5-HT2AR stimulation occurs in physiologic states or in SSRI-treated patients, but if it does, GPIb $\alpha$ shedding could affect cardiovascular outcome. SSRIs block 5HT uptake into platelets immediately with the onset of treatment, acutely raising extracellular 5-HT availability for 5-HT2AR stimulation [34]. Clinical studies have shown that post-myocardial infarction patients taking SSRIs are protected from reinfarction [35], and the mechanism reported here could contribute to this outcome.

\section{Supplementary Material}

Refer to Web version on PubMed Central for supplementary material.

\section{Acknowledgments}

We thank N. D. Horseman for kindly providing Tph1 $1^{-/-}$mice and L. Cowan for proofreading the manuscript. This work was supported by the National Heart, Lung and Blood Institute of the National Institutes of Health (grant PO 1 HL056949 to D. D. Wagner). M. Canault was supported by the Fondation pour la Recherche Médicale, France.

\section{References}

1. McNicol A, Israels SJ. Platelet dense granules: structure, function and implications for haemostasis. Thromb Res. 1999; 95:1-18. [PubMed: 10403682]

2. Li N, Wallen NH, Ladjevardi M, Hjemdahl P. Effects of serotonin on platelet activation in whole blood. Blood Coagul Fibrinolysis. 1997; 8:517-523. [PubMed: 9491270]

3. Cohen RA, Shepherd JT, Vanhoutte PM. Inhibitory role of the endothelium in the response of isolated coronary arteries to platelets. Science. 1983; 221:273-274. [PubMed: 6574604]

4. Walther DJ, Peter JU, Winter S, Holtje M, Paulmann N, Grohmann M, Vowinckel J, AlamoBethencourt V, Wilhelm CS, Ahnert-Hilger G, Bader M. Serotonylation of small GTPases is a 
signal transduction pathway that triggers platelet alpha-granule release. Cell. 2003; 115:851-862. [PubMed: 14697203]

5. Lesch KP, Wolozin BL, Murphy DL, Reiderer P. Primary structure of the human platelet serotonin uptake site: identity with the brain serotonin transporter. J Neurochem. 1993; 60:2319-2322. [PubMed: 7684072]

6. Killam AL, Cohen ML. Characterization of rat platelet serotonin receptors with tryptamine agonists and the antagonists: ketanserin and SCH 23390. Thromb Res. 1991; 64:331-340. [PubMed: 1805448]

7. Lesurtel M, Graf R, Aleil B, Walther DJ, Tian Y, Jochum W, Gachet C, Bader M, Clavien PA. Platelet-derived serotonin mediates liver regeneration. Science. 2006; 312:104-107. [PubMed: 16601191]

8. Dempsie Y, Morecroft I, Welsh DJ, MacRitchie NA, Herold N, Loughlin L, Nilsen M, Peacock AJ, Harmar A, Bader M, MacLean MR. Converging evidence in support of the serotonin hypothesis of dexfenfluramine-induced pulmonary hypertension with novel transgenic mice. Circulation. 2008; 117:2928-2937. [PubMed: 18506000]

9. Cote F, Fligny C, Bayard E, Launay JM, Gershon MD, Mallet J, Vodjdani G. Maternal serotonin is crucial for murine embryonic development. Proc Natl Acad Sci USA. 2007; 104:329-334. [PubMed: 17182745]

10. Hixson EJ, Lehrmann GV, Maickel RP. Contractile responses to tryptamine analogues in isolated smooth muscle. Arch Int Pharmacodyn Ther. 1977; 229:4-14. [PubMed: 931466]

11. Iken K, Chheng S, Fargin A, Goulet AC, Kouassi E. Serotonin upregulates mitogen-stimulated B lymphocyte proliferation through 5-HT1A receptors. Cell Immunol. 1995; 163:1-9. [PubMed: 7758118]

12. Durk T, Panther E, Muller T, Sorichter S, Ferrari D, Pizzirani C, Di Virgilio F, Myrtek D, Norgauer J, Idzko M. 5-Hydroxytryptamine modulates cytokine and chemokine production in LPS-primed human monocytes via stimulation of different 5-HTR subtypes. Int Immunol. 2005; 17:599-606. [PubMed: 15802305]

13. Gooz M, Gooz P, Luttrell LM, Raymond JR. 5-HT2A receptor induces ERK phosphorylation and proliferation through ADAM-17 tumor necrosis factor-alpha-converting enzyme (TACE) activation and heparin-bound epidermal growth factor-like growth factor (HB-EGF) shedding in mesangial cells. J Biol Chem. 2006; 281:21004-21012. [PubMed: 16737974]

14. Bergmeier W, Piffath CL, Cheng G, Dole VS, Zhang Y, von Andrian UH, Wagner DD. Tumor necrosis factor-alpha-converting enzyme (ADAM17) mediates GPIbalpha shedding from platelets in vitro and in vivo. Circ Res. 2004; 95:677-683. [PubMed: 15345652]

15. Maxwell MJ, Westein E, Nesbitt WS, Giuliano S, Dopheide SM, Jackson SP. Identification of a 2stage platelet aggregation process mediating shear-dependent thrombus formation. Blood. 2007; 109:566-576. [PubMed: 16990596]

16. Ruggeri ZM, Mendolicchio GL. Adhesion mechanisms in platelet function. Circ Res. 2007; 100:1673-1685. [PubMed: 17585075]

17. Bergmeier W, Piffath CL, Goerge T, Cifuni SM, Ruggeri ZM, Ware J, Wagner DD. The role of platelet adhesion receptor GPIbalpha far exceeds that of its main ligand, von Willebrand factor, in arterial thrombosis. Proc Natl Acad Sci USA. 2006; 103:16900-16905. [PubMed: 17075060]

18. Peschon JJ, Slack JL, Reddy P, Stocking KL, Sunnarborg SW, Lee DC, Russell WE, Castner BJ, Johnson RS, Fitzner JN, Boyce RW, Nelson N, Kozlosky CJ, Wolfson MF, Rauch CT, Cerretti DP, Paxton RJ, March CJ, Black RA. An essential role for ecto-domain shedding in mammalian development. Science. 1998; 282:1281-1284. [PubMed: 9812885]

19. Walther DJ, Peter J-U, Bashammakh S, Hortnagl H, Voits M, Fink H, Bader M. Synthesis of serotonin by a second tryptophan hydroxylase isoform. Science. 2003; 299:76. [PubMed: 12511643]

20. Kanaji T, Russell S, Ware J. Amelioration of the macrothrombocytopenia associated with the murine Bernard-Soulier syndrome. Blood. 2002; 100:2102-2107. [PubMed: 12200373]

21. Cifuni SM, Wagner DD, Bergmeier W. CalDAG-GEFI and protein kinase C represent alternative pathways leading to activation of integrin alphaIIbbeta3 in platelets. Blood. 2008; 112:1696-1703. [PubMed: 18544684] 
22. Monroe DM, Hoffman M. What does it take to make the perfect clot? Arterioscler Thromb Vasc Biol. 2006; 26:41-48. [PubMed: 16254201]

23. Carneiro AM, Cook EH, Murphy DL, Blakely RD. Interactions between integrin alphaIIbbeta3 and the serotonin transporter regulate serotonin transport and platelet aggregation in mice and humans. J Clin Invest. 2008; 118:1544-1552. [PubMed: 18317590]

24. Yu B, Becnel J, Zerfaoui M, Rohatgi R, Boulares AH, Nichols CD. Serotonin 5hydroxytryptamine(2A) receptor activation suppresses tumor necrosis factor-alpha-induced inflammation with extraordinary potency. J Pharmacol Exp Ther. 2008; 327:316-323. [PubMed: 18708586]

25. Rabie T, Strehl A, Ludwig A, Nieswandt B. Evidence for a role of ADAM17 (TACE) in the regulation of platelet glycoprotein V. J Biol Chem. 2005; 280:14462-14468. [PubMed: 15691827]

26. Gardiner EE, Karunakaran D, Shen Y, Arthur JF, Andrews RK, Berndt MC. Controlled shedding of platelet glycoprotein (GP)VI and GPIb-IX-V by ADAM family metalloproteinases. J Thromb Haemost. 2007; 5:1530-1537. [PubMed: 17445093]

27. Nagatomo T, Rashid M, Abul Muntasir H, Komiyama T. Functions of 5-HT2A receptor and its antagonists in the cardiovascular system. Pharmacol Ther. 2004; 104:59-81. [PubMed: 15500909]

28. Bergmeier W, Rackebrandt K, Schroder W, Zirngibl H, Nieswandt B. Structural and functional characterization of the mouse von Willebrand factor receptor GPIb-IX with novel monoclonal antibodies. Blood. 2000; 95:886-893. [PubMed: 10648400]

29. Wgner A, Montero D, Martensson B, Siwers B, Asberg M. Effects of fluoxetine treatment of platelet $3 \mathrm{H}$-imipramine binding, 5-HT uptake and 5-HT content in major depressive disorder. $\mathrm{J}$ Affect Disord. 1990; 20:101-113. [PubMed: 2176228]

30. Benedict CR, Mathew B, Rex KA, Cartwright J Jr, Sordahl LA. Correlation of plasma serotonin changes with platelet aggregation in an in vivo dog model of spontaneous occlusive coronary thrombus formation. Circ Res. 1986; 58:58-67. [PubMed: 3943156]

31. Millan MJ, Marin P, Bockaert J, Mannoury la Cour C. Signaling at G-protein-coupled serotonin receptors: recent advances and future research directions. Trends Pharmacol Sci. 2008; 29:454464. [PubMed: 18676031]

32. Labasque M, Reiter E, Becamel C, Bockaert J, Marin P. Physical interaction of calmodulin with the 5-HT2C receptor C-terminus is essential for G protein-independent, arrestin-dependent, receptor signaling. Mol Biol Cell. 2008; 19:4640-4650. [PubMed: 18768750]

33. McLaughlin NJ, Banerjee A, Kelher MR, Gamboni-Robertson F, Hamiel C, Sheppard FR, Moore EE, Silliman CC. Platelet-activating factor-induced clathrin-mediated endocytosis requires betaarrestin-1 recruitment and activation of the $\mathrm{p} 38$ MAPK signalosome at the plasma membrane for actin bundle formation. J Immunol. 2006; 176:7039-7050. [PubMed: 16709866]

34. Rothman RB, Zolkowska D, Baumann MH. Serotonin (5-HT) transporter ligands affect plasma 5HT in rats. Ann NY Acad Sci. 2008; 1139:268-284. [PubMed: 18991872]

35. Taylor CB, Youngblood ME, Catellier D, Veith RC, Carney RM, Burg MM, Kaufmann PG, Shuster J, Mellman T, Blumenthal JA, Krishnan R, Jaffe AS. Effects of antidepressant medication on morbidity and mortality in depressed patients after myocardial infarction. Arch Gen Psychiatry. 2005; 62:792-798. [PubMed: 15997021] 

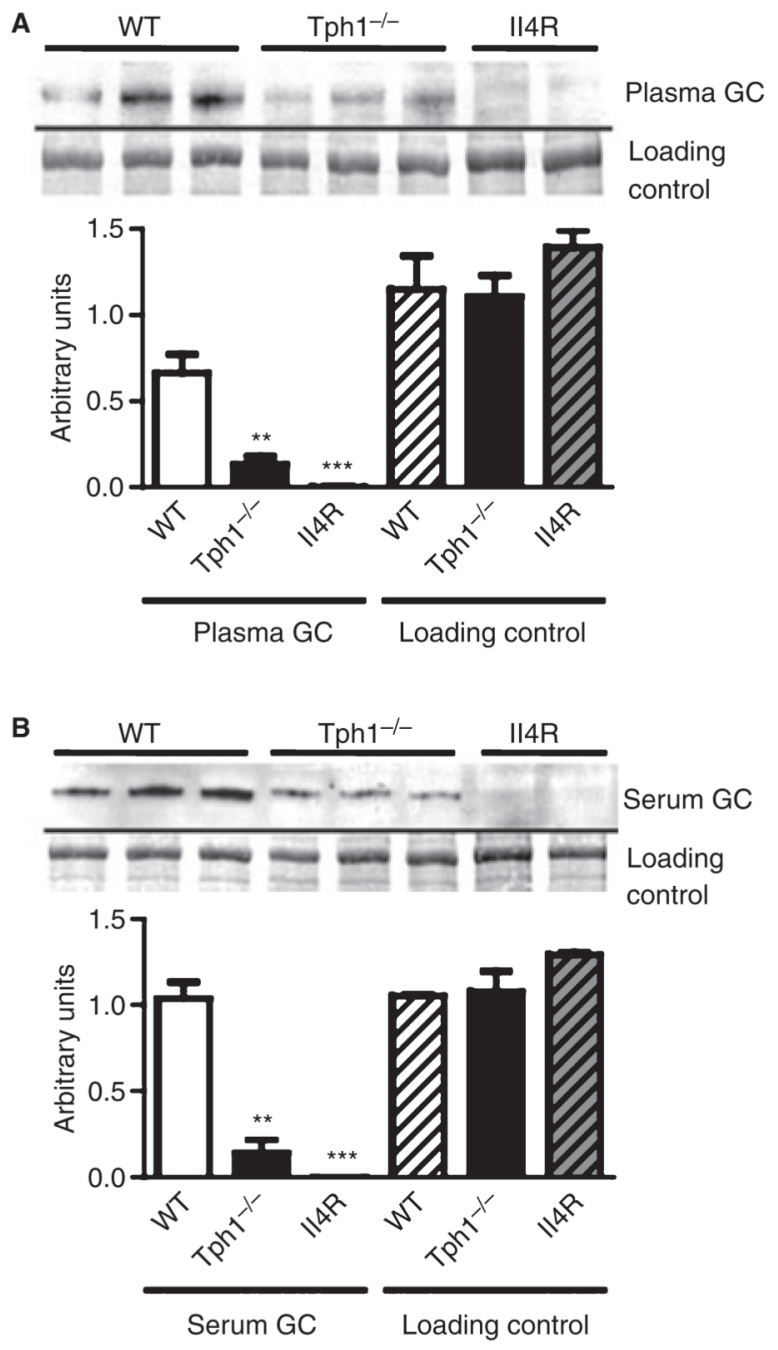

C

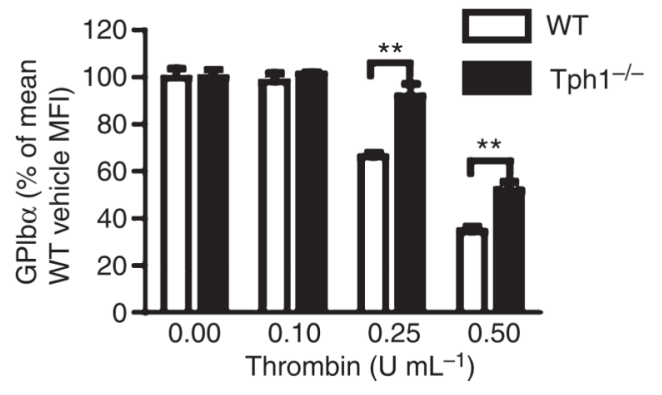

Fig. 1.

5-Hydroxytryptamine deficiency affects shedding of glycoprotein (GP)Iba. (A) Plasma glycocalicin (GC) was detected by western blot [representative for 11 wild-type (WT), 11 Tph $1^{-/-}$and four interleukin-4 receptor $\alpha$ (IL-4R $\alpha$ )/GPIb $\alpha$ transgenic (IL-4R) mice]. Total protein was stained with Coomassie blue (loading control). Areas of bands were quantified (bar graph). (B) Glycocalicin and a Coomassie blue-stained protein in serum $(n=5)$. (C) Surface GPIb $\alpha$ was measured by flow cytometry after treatment of isolated platelets with thrombin for $10 \min (n=5)$. MFI, mean fluorescence intensity; $* * P<0.01$ and $* * * P<$ 0.001 as compared with the wild type. 

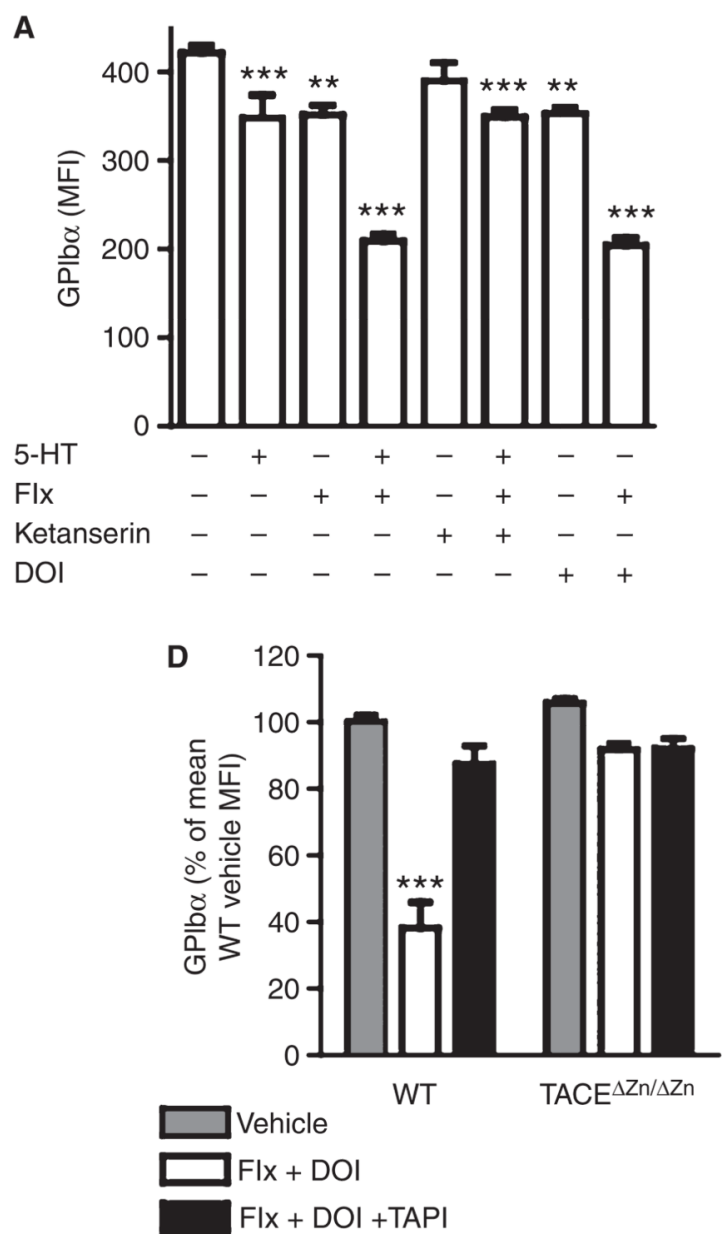

B

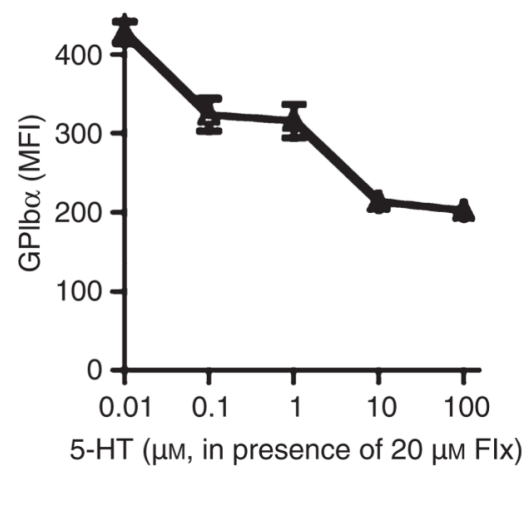

C

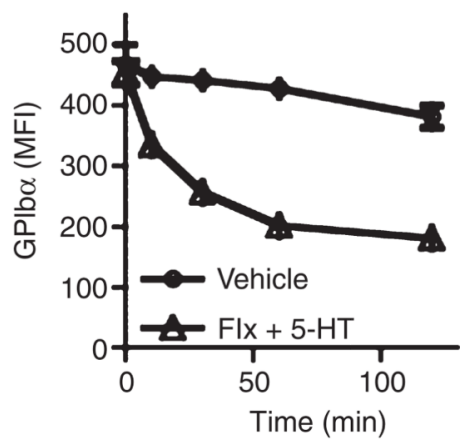

E

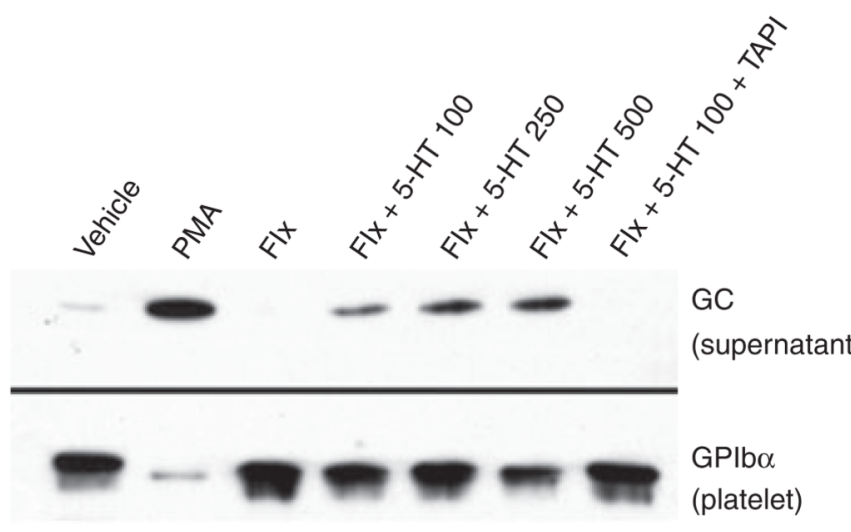

Fig. 2.

Stimulation of membrane 5-hydroxytryptamine receptor (5-HT2AR) induces tumor necrosis factor-alpha-converting enzyme (TACE)-mediated glycoprotein (GP)Ib $\alpha$ shedding. (A) Isolated wild-type (WT) platelets were incubated with $100 \mu_{\mathrm{M}} 5-\mathrm{HT}, 20 \mu_{\mathrm{M}}$ fluoxetine (Flx), $20 \mu_{\mathrm{M}}$ ketanserin, $50 \mu_{\mathrm{M}}(-)$-2,5-dimethoxy-4-iodoamphetamine hydrochloride (DOI) or dimethylsulfoxide (DMSO) (vehicle) as indicated, and surface GPIb $\alpha$ was measured by flow cytometry $(n \geq 8$ mice). (B) Dose-dependency (60-min incubation) and (C) timedependency $\left(100 \mu_{\mathrm{M}} 5-\mathrm{HT}\right)$ of GPIb $\alpha$ decrease with 5-HT and $20 \mu_{\mathrm{M}}$ fluoxetine $(n=5)$. (D) GPIb $\alpha$ levels after $20 \mu_{\mathrm{M}}$ fluoxetine/50 $\mu_{\mathrm{M}}$ DOI $(n=8)$ incubation with or without TACE inhibition by $5 \mu_{\mathrm{M}}$ tumor necrosis factor-alpha protease inhibitor (TAPI-1). (E) Glycocalicin in supernatant of wild-type platelets after incubation with $20 \mu_{\mathrm{M}}$ fluoxetine and 5-HT at the indicated concentrations, $300 \mathrm{n}_{\mathrm{M}}$ phorbol 12-myristate 13-acetate (PMA), and $5 \mu_{\mathrm{M}}$ TAPI-1 (representative of three western blot analyses; other blots showed a stronger band after fluoxetine than after vehicle treatment). Below, GPIb $\alpha$ in lysed platelets from the same samples. ${ }^{* * *} P<0.001$ as compared with wild type/vehicle. MFI, mean fluorescence intensity. 
A

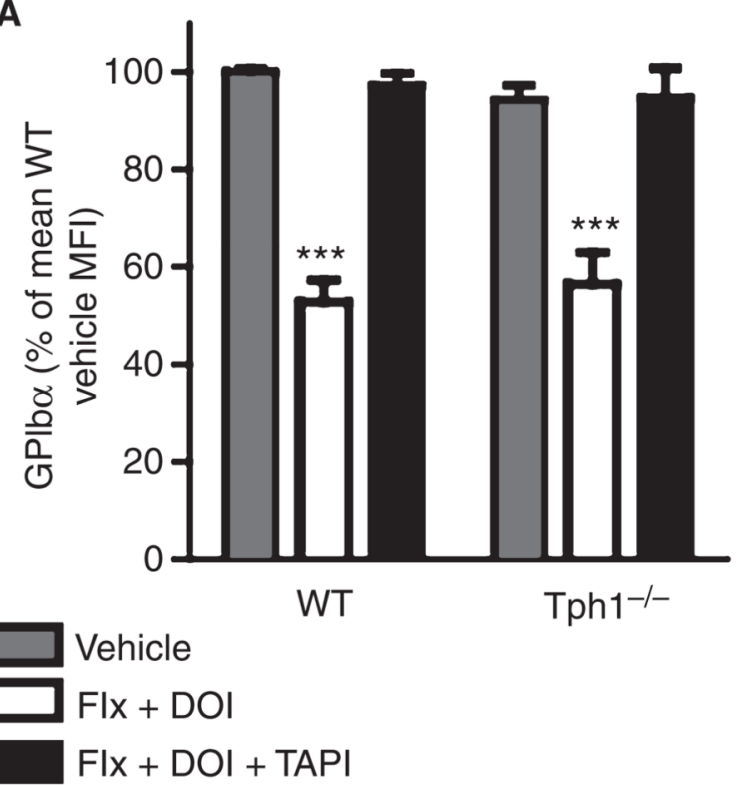

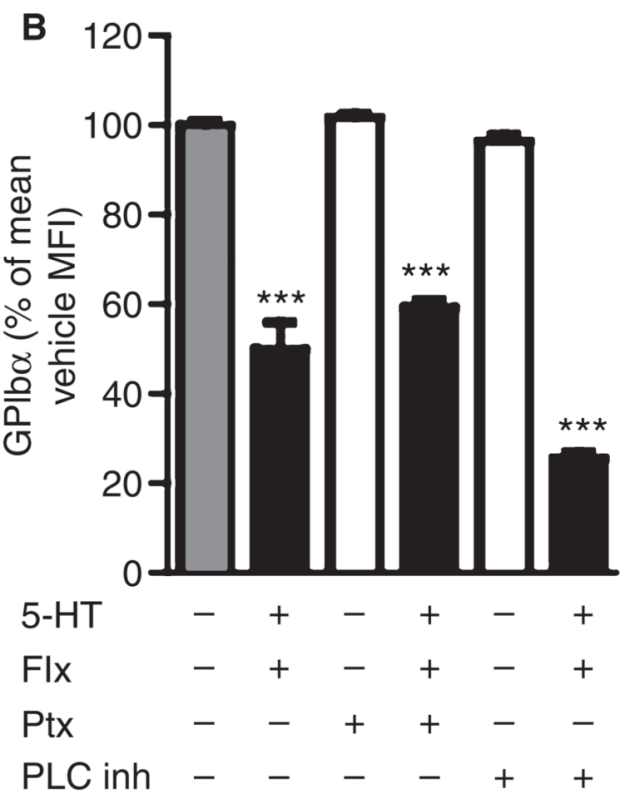
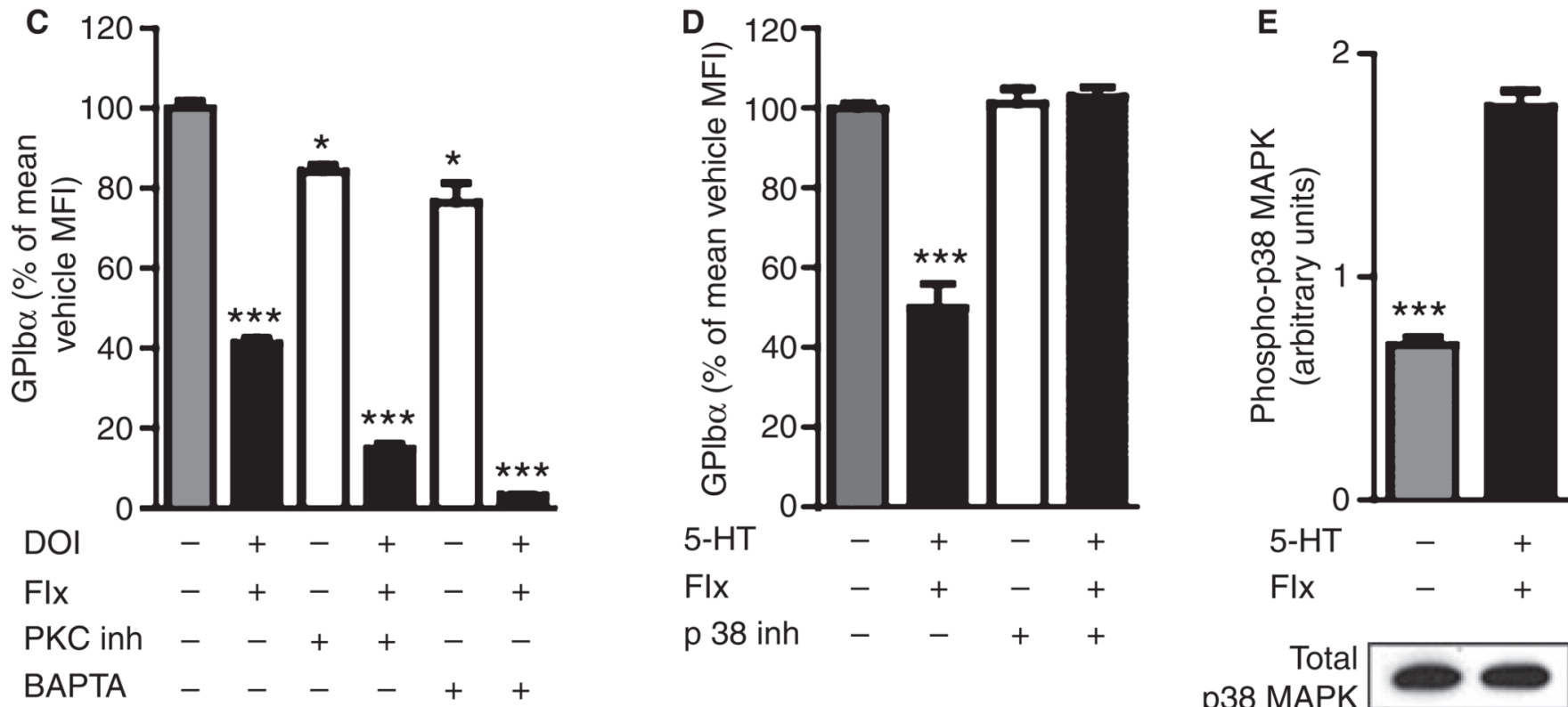

Fig. 3.

p38 Mitogen-activated protein kinase (MAPK) mediates tumor necrosis factor-alphaconverting enzyme activation after membrane 5-hydroxytryptamine receptor (5-HT2AR) stimulation. (A) Glycoprotein (GP)Ib $\alpha$ on isolated platelets after $20 \mu_{\mathrm{M}}$ fluoxetine (Flx), 50 $\mu_{\mathrm{M}}(-)$-2,5-dimethoxy-4-iodoamphetamine hydrochloride (DOI) and $5 \mu_{\mathrm{M}}$ tumor necrosis factor-alpha protease inhibitor (TAPI-1) incubation as indicated ( $n \geq 6$ mice). (B) Signal transduction by pertussis toxin (Ptx)-sensitiveG-proteins was inhibited by $10 \mu \mathrm{g} \mathrm{mL}^{-1} \mathrm{Ptx}$ or the phospholipase C (PLC) inhibitor U73122 (10 $\left.\mu_{\mathrm{M}}, n=4\right)$ in wild-type (WT) platelets. (C) Protein kinase $\mathrm{C}(\mathrm{PKC})$ was inhibited with $5 \mu \mathrm{g} \mathrm{mL}^{-1}$ Ro31-8220, and intracellular $\mathrm{Ca}^{2+}$ was chelated with $30 \mu_{\mathrm{M}}$ BAPTA $(n=4)$. (D) Signaling through p38 MAPK was inhibited by $20 \mu_{\mathrm{M}} \mathrm{SB} 203580(n=6)$. (E) Phosphorylation of p38 MAPK after 15 min of incubation with $20 \mu_{\mathrm{M}}$ fluoxetine and $100 \mu_{\mathrm{M}} 5$-HT was determined by enzyme-linked 
immunosorbent assay and p38MAPK protein in the same samples by western blot (representative blot, $n=3$ ). $* P<0.05$ and ${ }^{* * *} P<0.001$ as compared with wild type/vehicle. 
A

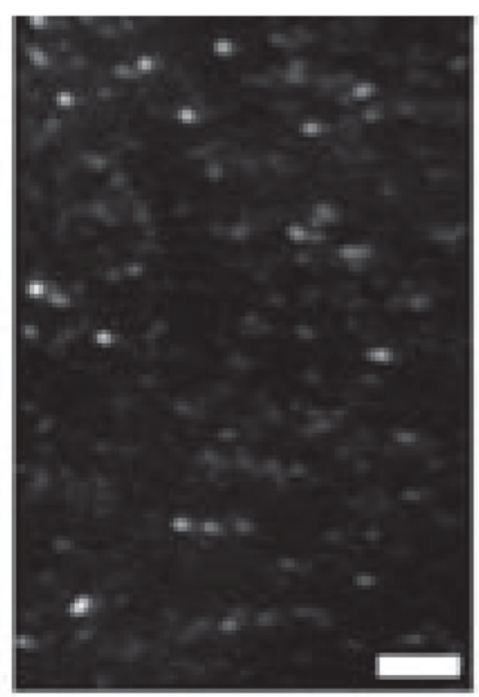

Vehicle

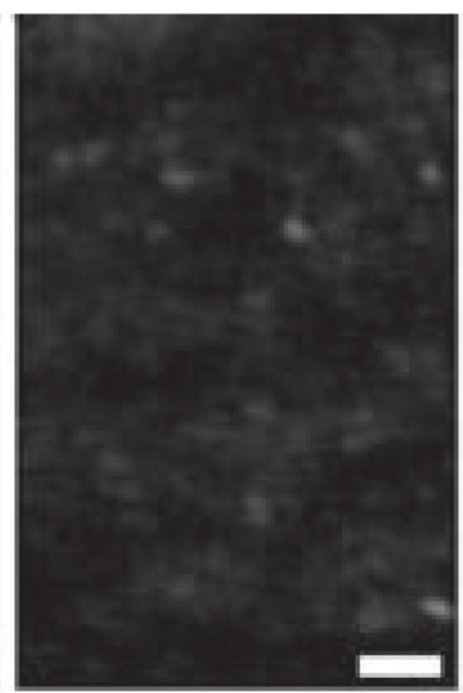

$\mathrm{Flx}+\mathrm{DOI}$

B

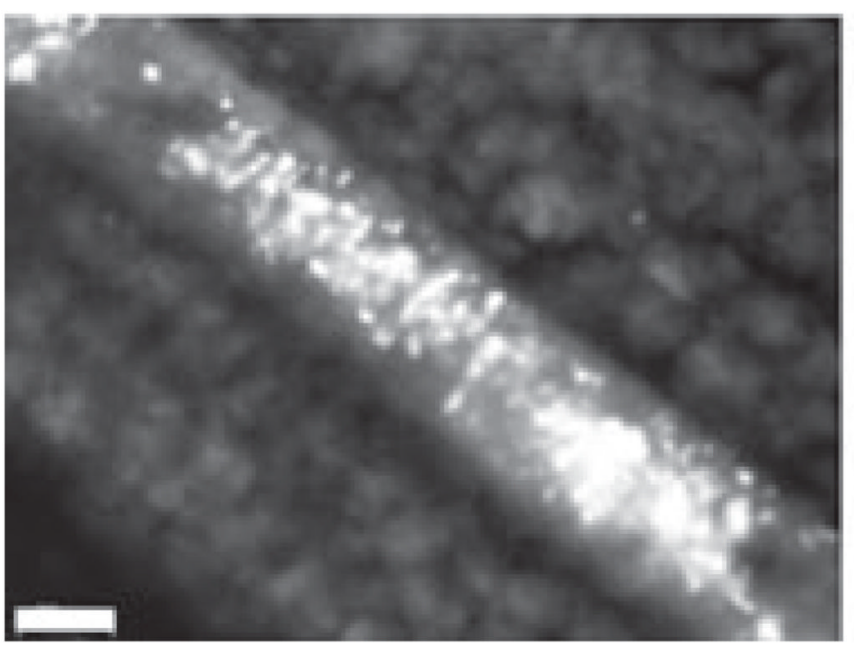

Vehicle

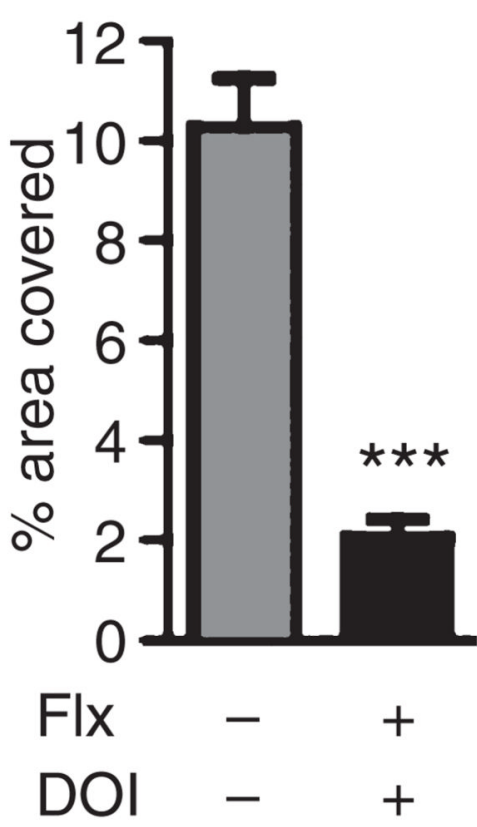

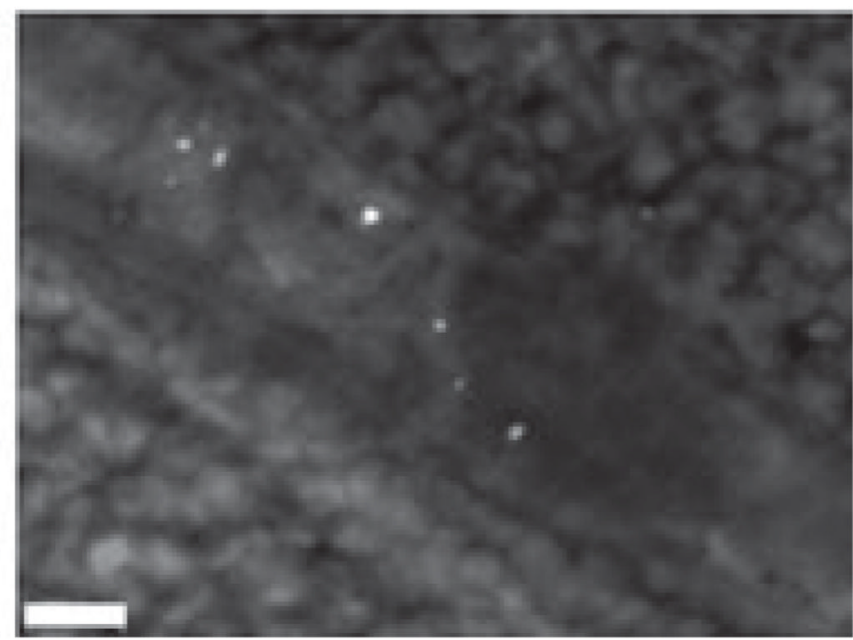

$\mathrm{Flx}+5-\mathrm{HT}$

Fig. 4.

Platelet adhesion is impaired after membrane 5-hydroxytryptamine receptor (5-HT2AR) stimulation. (A) Flow chamber: labeled wild-type platelets treated with dimethylsulfoxide (vehicle) or $20 \mu_{\mathrm{M}}$ fluoxetine (Flx) plus $50 \mu_{\mathrm{M}}$ (-)-2,5-dimethoxy-4-iodoamphetamine hydrochloride (DOI) were resuspended in platelet-poor blood and perfused over collagen at arterial shear rates $\left(1500 \mathrm{~s}^{-1}\right)$. The covered area was quantified after $2 \mathrm{~min}$ (bar graph, $n=$ 10). (B) Incorporation of labeled wild-type platelets after in vitro treatment with $20 \mu_{\mathrm{M}}$ fluoxetine and $100 \mu_{\mathrm{M}} 5$-HT into thrombi was assessed in mesenteric arterioles after endothelial denudation with $10 \% \mathrm{FeCl}_{3}$ (occluding thrombi in separate mice shown, representative for $n=5$ ). White bar represents $50 \mu \mathrm{m}$. 


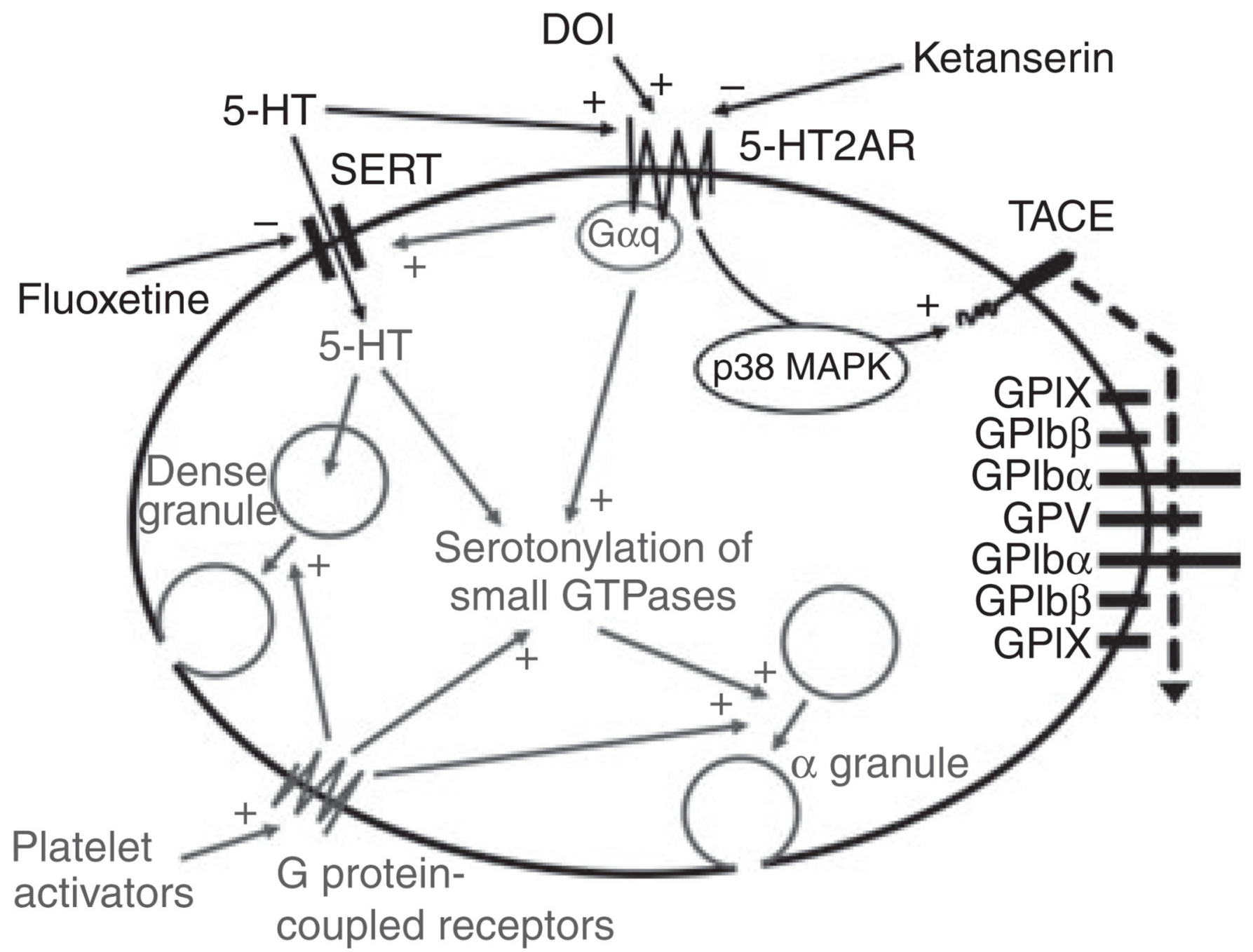

Fig. 5.

Schematic of 5-hydroxytryptamine (5-HT) actions in platelets. After uptake by 5-HT transporter (SERT) in resting platelets, 5-HT is stored in dense granules, from which it is released upon activation. High intracellular 5-HT concentrations, together with platelet activation by other agonists, leads to serotonylation of small GTPases and $\alpha$-granule release. Binding of 5-HT to membrane 5-HT receptor (5-HT2AR) activates tumor necrosis factoralpha-converting enzyme (TACE) and leads to shedding of glycoprotein (GP)Ib $\alpha$ and GPV, which is mediated by p38 mitogen-activated protein kinase (MAPK) and is independent of G-protein signaling. Known 5-HT actions in gray; +, stimulation; -, inhibition. DOI, (-)-2,5-dimethoxy-4-iodoamphetamine hydrochloride. 